\title{
Working Cell Bank Release Laboratory Testing
}

National Cancer Institute

\section{Source}

National Cancer Institute. Working Cell Bank Release Laboratory Testing. NCI Thesaurus.

Code 1113022.

Testing of cell bank specimens for microbial contamination. 